\title{
Recycling of Municipal Solid Waste in Sinop, Turkey: Practices, Problems and Challenges
}

\section{Oylum Gökkurt BAKI $\dot{I}^{1 *}$, Osman Nuri ERGUN², Ahu NOGAY ${ }^{3}$}

\begin{abstract}
In this study, recycling potentiality of municipal solid wastes of the province of Sinop, being a significant coastal town of Central Black Sea in terms of tourism. The studies related to nonhazardous kinds of wastes formed within the borders of the province have been assessed. The compositions and the changes in the amounts of the wastes formed in the province have been analyzed and assessed in association with the consumption habits. The composition of the recyclable wastes among the municipal solid wastes in the province and the management of these wastes have been studied. The amount of municipal solid wastes occurred has been determined and the mount of the wastes recycled by these wastes has been detected and thus the recycling activities started in the region have been evaluated. Recycling activities started in some regions of the province for recyclable urban wastes such as paper, carton, glass, metal and plastic etc., which are of high incidence within waste composition have been assessed. The analysis and evaluation of the studies conducted to some districts of the city related to packing wastes and management have been conducted. Therefore, applicability of recycling works and management of municipal solid waste in the city has been assessed and besides this "sustainability" has been researched. Furthermore, research and evaluation on production, collectiontransportation, recycling applications and phases of these wastes, having an economic value and evaluation on the issue have been carried out in the study.
\end{abstract}

Keywords: Waste management, recycling, municipal waste, sustainability.

\footnotetext{
${ }^{1}$ Oylum GÖKKURT BAKİ (Orcid ID: 0000-0001-7823-0824), Sinop University, Engineering and Architecture Faculty, Environmental Engineering Department, Sinop, Turkey

${ }^{2}$ Osman Nuri ERGUN, Ondokuz Mayis University, Engineering Faculty, Environmental Engineering Department, Samsun, Turkey

${ }^{3}$ Ahu NOGAY, Sinop University, Institue of Science, Environmental Health Programme, Sinop, Turkey

*Sorumlu Yazar/Corresponding Author: Oylum GÖKKURT BAKİ, e-mail: oylumbaki@gmail.com

Makale 11-14 Mayıs 2016 tarihinde Kastamonu’da düzenlenen “8. Ulusal Katı Atık Yönetimi Kongresi UKAY’2016”da poster olarak sunulmuştur.
} 


\section{INTRODUCTION}

Solid waste management includes the entire process of the formation, transport, sorting, recycling, and lastly disposal of the waste. To manage this process well, firstly the composition, amount and characteristic of the waste should be known. It is very important to define the waste and know its characteristics in selecting the disposal method to be applied in the waste management process of these characteristics changing with respect to many factors. Waste management is a topic, which needs to be discussed with the system approach. System approach requires addressing the main elements of the waste management like waste formation, collection, processing and disposal, as well as other topics, such as energy, environmental protection, and the conservation of resources, productivity growth and employment in a holistic way. The system approach in waste management will make positive contributions to economic development by not only removing solid wastes from human environment, but also protecting and developing environmental and human health (Palabıyık and Altunbaş, 2004; Fettahoğlu, 2011). Increasing population levels, booming economy, rapid urbanization and the rise in community living standards have greatly accelerated the municipal solid waste generation rate in developing countries (Guerrero et al., 2013; Minghua, 2009) as in our country. And also, municipal solid waste generally includes degradable and recyclable such as paper, textiles, food waste, straw and yard waste and non-degradable and again recyclable materials such as leather, plastics, rubbers, metals, glass, ash from fuel burning like coal, briquettes or woods, dust and electronic waste (Gupta, et al., 2015; Jha, 2011; Herat, 2009; Tchobanoglous et al., 1993).

This study investigates the recovery possibilities of municipal solid wastes in the city center of Sinop. The municipal wastes formed in the city center with recycling potentials were considered. In the city, high, medium and low income levels of the regions having different consumption habits were combined. Diversity and change in the amounts of wastes formed in the city were investigated and then compared. The applicability of municipal waste solid management and recycling activities were investigated and suggestions about the sustainability of these activities were made.

\section{MATERIAL AND METHOD}

Sinop, which is in the Central Black Sea Region and Turkey's northernmost point, is located on a peninsula surrounded by the sea with three sides. Sinop, surrounded by Kastamonu to the west, Çorum to the south, and Samsun to the east, are at $41^{\circ} 12^{\prime}-42^{\circ} 06^{\prime}$ northern latitudes and $34^{\circ} 14^{\prime}-35^{\circ} 26^{\prime}$ east longitudes. The location of Sinop on the Turkey's map is shown in Figure 1 (Anonymous, 2006).

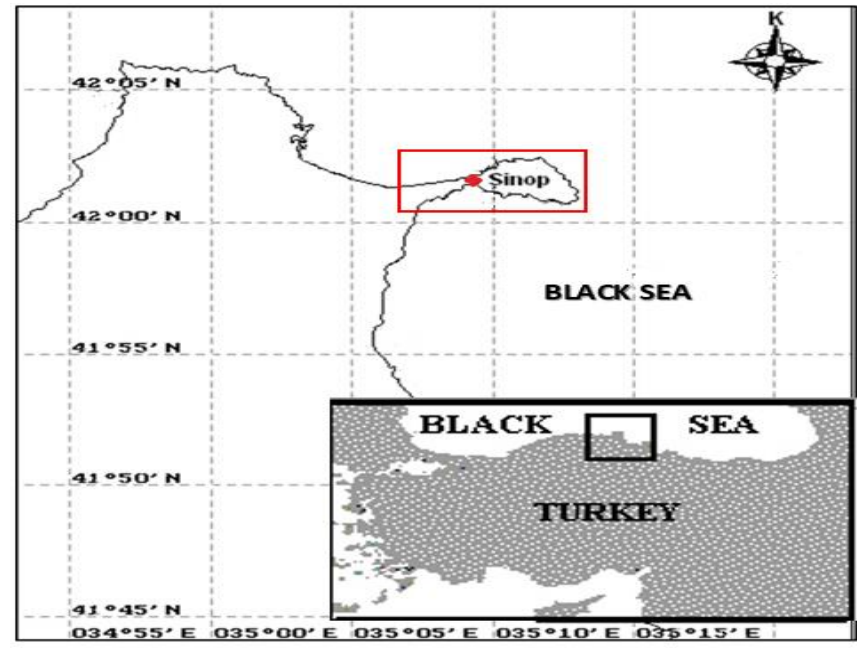

Figure 1. The map of study area 
The land border of the city is $300 \mathrm{~km}$ long and its coastal length is $175 \mathrm{~km}$ (SCOM, 2005). There are two harbors in the city with one in the northwest and one in the southeast. The main harbor is located in a bay in the southeastern. Akliman and Hamsilos Bays located in the northwest are important shelters of ancient times (MSU, 2005). In the Sinop Peninsula where the climate specific to the Black Sea Region dominates, spring and autumn is cool and heavy rainy while winter is rainy, humid and cold. The summers are short and warm. In Sinop, there are 45 people per $\mathrm{km}^{2}$ in the provincial but 124 people per $\mathrm{km}^{2}$ in the city center where the population is the most concentrated (SB, 2009). It is a moderate-level developed city in terms of education level.

The project area is located inside the city center borders of Sinop; on the geographical coordinates of $41^{\circ} 56^{\prime} 25^{\prime}$ ' northern latitudes, and 35 $02^{\prime} 40^{\prime}$ ' east longitudes and in a region called Meşedağı District restricted by Sinop-Gerze State Road to the west, Eldevüz to the east, Yenimahalle to the north and Uzungürgen villages to the south (Anonymous, 2006). In the scope of the works performed leading by Sinop Municipality, the project area is one of the Solid Waste areas that have a landfill of 30 hectares. After accomplishing the 'Meşedağı' project entitled by the name of the region, the common landfill of Sinop province and Gerze, and Erfelek counties was created (Anonymous, 2008). The site will meet the need of the project area for solid waste storage for approximately 15 years. Table 1 shows the information about the capacity of the site (Anonymous, 2006).

Table 1. Solid waste landfill information (Anonymous, 2017a)

\begin{tabular}{ccccccc}
\hline $\begin{array}{c}\text { Population } \\
\text { (2015) }\end{array}$ & \multicolumn{2}{c}{$\begin{array}{c}\text { Recycling and storage } \\
\text { facilities }\end{array}$} & \multicolumn{2}{c}{$\begin{array}{c}\text { Regular storage } \\
\text { coordinates }\end{array}$} & \multicolumn{2}{c}{ Waste amount (tonnes.day ${ }^{-1}$ ) } \\
\hline & Municipality & $\begin{array}{c}\text { Private } \\
\text { sector }\end{array}$ & Y & $\mathbf{X}$ & Normal season & Busy season \\
\hline 110.617 & & $\mathrm{X}$ & 41.94892 & 35.03675 & 75.64 \\
\hline \multicolumn{2}{c}{ Waste composition } & & \multicolumn{4}{c}{ Storage facility } \\
\hline $\begin{array}{c}\text { Domestic } \\
\text { organic }\end{array}$ & Recyclability & Inert & $\begin{array}{c}\text { Solidity ratio } \\
(\boldsymbol{\%})\end{array}$ & Capacity & $\begin{array}{c}\text { Permission } \\
\text { License Startup }\end{array}$ & $\begin{array}{c}\text { Permission } \\
\text { License end }\end{array}$ \\
\hline 46.55 & 41.23 & 12.22 & $\% 22$ & 555.000 & 2013 & 2018 \\
\hline
\end{tabular}

This study consisted of two stages. The first collecting data from and the second evaluating of municipal solid waste data with potential for recycling. The municipal solid waste data collecting was done in 2015 and beginning of 2016 (January, February and March of 2016). When evaluating the recycling potential of wastes, $\%$ values of wastes with recycling potential are taken into consideration based on years. The data were taken from the municipality records of 2015 and beginning of 2016. Sinop Municipality does not implement any waste separation in the sanitary landfill. The percentages of wastes that are likely to be recycled were determined from the obtained data and the unit prices of recycling potential waste were determined and evaluated.

\section{RESULTS AND DISCUSSION}

The amounts of waste formed in the study area are shown in Table 2. Although the amount of recyclable waste is $18 \%$, it is not possible to entirely separate it. The separation works are performed with approximately $5 \%$ wastage. There is a high loss in the amount of waste to be recycled because wastes cannot be collected separately at the 'source' (Gokkurt Baki and Ergun, 2015).

The recycling potential of overall wastes was determined to be $18 \%$ in this study. This value was used as a base in the recycled amount calculations in the waste projection. Figure 2 shows the amounts of domestic waste and recyclable waste for Sinop. 
Table 2. Waste projection (Anonymous, 2006; 2008)

\begin{tabular}{|c|c|c|c|c|c|c|c|c|}
\hline \multirow{2}{*}{$\stackrel{\Xi}{\varpi}$} & \multirow{2}{*}{ 总 } & \multicolumn{3}{|c|}{ Domestic solid waste } & \multirow{2}{*}{\begin{tabular}{|c|}
$\begin{array}{c}\text { Amount } \\
\text { of } \\
\text { recycling }\end{array}$ \\
$\begin{array}{c}\text { ton. } \\
\text { year }^{-1}\end{array}$ \\
\end{tabular}} & \multicolumn{2}{|c|}{ Amount of storage } & \multirow{2}{*}{$\begin{array}{c}\begin{array}{c}\text { Waste of } \\
\text { added } \\
\text { waste }\end{array} \\
\begin{array}{c}\mathbf{m}^{3} . \\
\text { year }^{-1}\end{array}\end{array}$} \\
\hline & & $\begin{array}{l}\text { kg. } \\
\text { person } \\
\text {.gün}^{1}\end{array}$ & $\begin{array}{l}\text { ton. } \\
\text { day }^{-1}\end{array}$ & $\begin{array}{c}\text { ton. } \\
\text { year-1 }^{-1}\end{array}$ & & $\begin{array}{c}\text { ton. } \\
\text { year }^{-1}\end{array}$ & $\begin{array}{c}\mathbf{m}^{3} . \\
\text { year }^{-1}\end{array}$ & \\
\hline 2005 & 62291 & 0.9 & 56 & 20440 & 1226 & 19214 & 27449 & 27449 \\
\hline 2006 & 63517 & 0.9 & 57 & 20805 & 1248 & 19557 & 27939 & 27939 \\
\hline 2007 & 64770 & 0.9 & 58 & 21170 & 1270 & 19900 & 28429 & 56368 \\
\hline 2008 & 66049 & 0.9 & 59 & 21535 & 1292 & 20243 & 28919 & 85287 \\
\hline 2009 & 67336 & 0.9 & 61 & 22265 & 1336 & 20929 & 29899 & 115186 \\
\hline 2010 & 68690 & 0.9 & 62 & 22630 & 1358 & 21272 & 30389 & 145575 \\
\hline 2011 & 70053 & 0.9 & 63 & 22995 & 1380 & 21615 & 30879 & 176454 \\
\hline 2012 & 71446 & 0.9 & 64 & 23360 & 1402 & 21958 & 31369 & 207823 \\
\hline 2013 & 72868 & 0.9 & 66 & 24090 & 1445 & 22645 & 32350 & 240173 \\
\hline 2014 & 74321 & 0.9 & 67 & 24455 & 1467 & 22988 & 32840 & 273013 \\
\hline 2015 & 75805 & 1.2 & 91 & 33215 & 1993 & 31222 & 44603 & 317616 \\
\hline
\end{tabular}

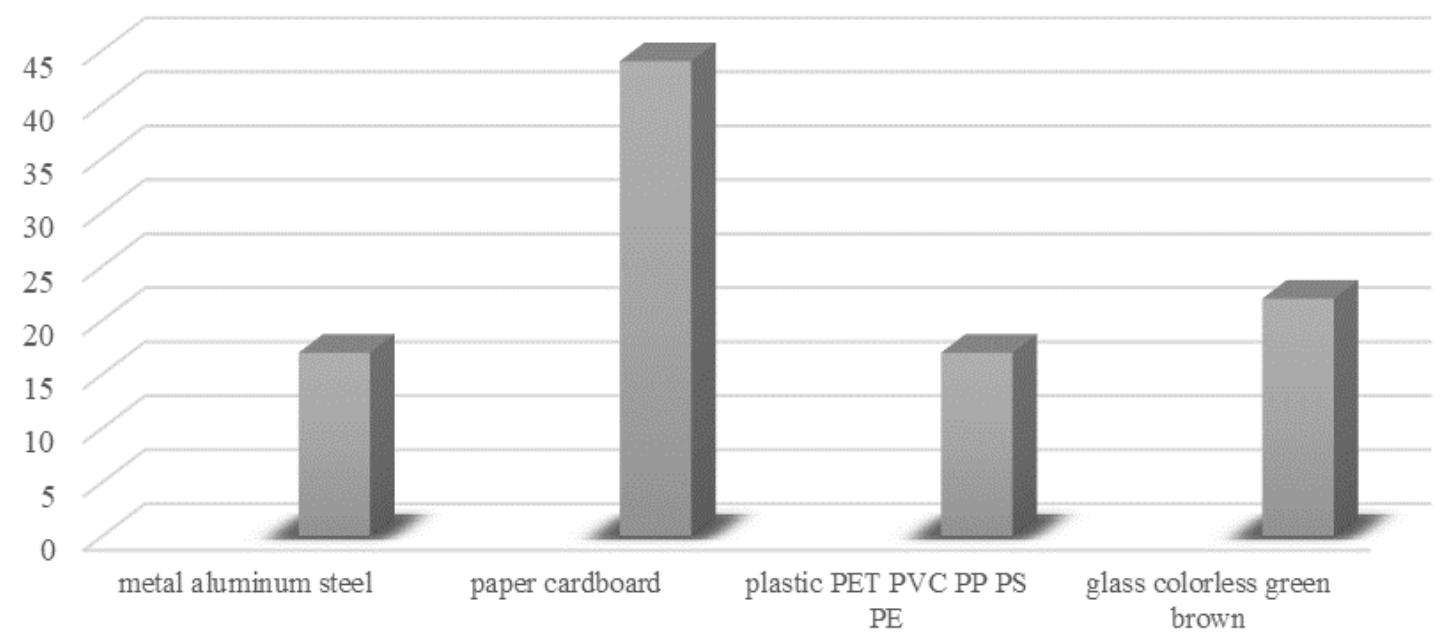

Figure 2. Distribution of recyclable materials for Sinop Provincial Center (IB, 2004)

The collection of municipal solid wastes in the city center of Sinop is carried out with containers and special vehicles. The collection of municipal mixed packaging wastes formed in the region were carried out daily by a private waste collection and recycling company. Garbage collection is done every day except Sundays and two times a week in neighborhoods. The collection process is performed between 08:00-20:00 hours during the daytime.

One of the most important problems of solid wastes is their accumulation and collection. In Turkey, garbage are accumulated in an unhealthy way in waste storage containers on streets and left to irregular waste areas by trash men. Today, in the world, while healthy and economical models are being developed for the issues about accumulating solid wastes in a healthy way and collecting them separately at the source, most of the recyclable materials in Turkey are collected from garbage areas in an unhealthy way (Turan and Ekmekyapar, 2009).

The recyclable management of municipal wastes in the region is carried out within the scope of "The Separate Collection at Source, Transport and Recovery of Packaging Wastes Process Implementing Procedures and Principles Protocol" signed between Provincial Municipality and Licensed Company. As the accumulation method, packaging waste units are directly placed in the vicinity of companies especially having high amounts of packaging wastes and wastes are accumulated and then collected in these units. The collection process is carried out with three workers and two vehicles belonging to the 
Municipality. One of these vehicles is a compressive-type and the other is a van-type vehicle. Vehicles belonging to both the Municipality and authorized company provide service six days a week. The authorized company supplied the followings to the city center for collecting mixed packaging wastes: 10 containers in 2012, 30 cage trashcans in 2013, 20 cage trashcans in 2014, and 30 containers in 2015. As of the beginning of 2016, a total of 120 containers were placed, out of 30 for primary education institutions. Figure 3 shows the seasonal changes of mixed packaging amounts in 2015 while Figure 4 shows the comparison of total waste and recovery data of 2015.

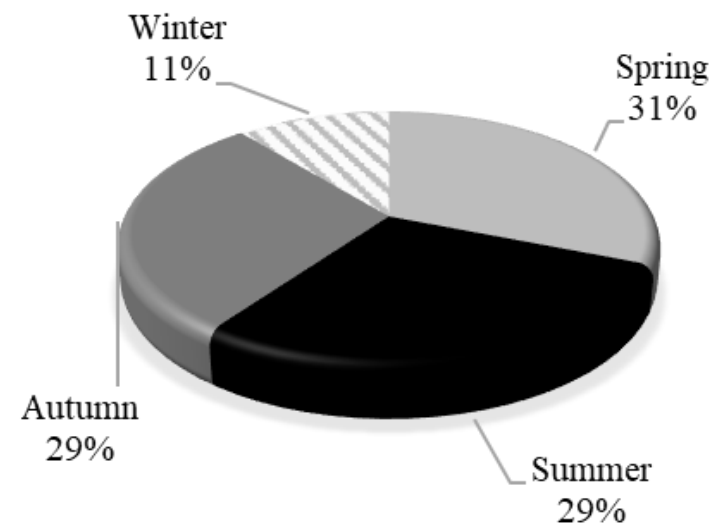

Figure 3. Seasonal variation of mixed packaging quantities for 2015 ( Anonymous, 2017a)

Collection is carried out from recycling cages located in markets, schools and various government offices. In the first three months of 2016, 22 tons of paper-cardboard, 1.5 tons of plastic and $500-600 \mathrm{~kg}$ of glass wastes were collected for recycling. There are two street recycling collectors under registration. As can be seen from Figure 4, the amount of summer and winter wastes in Sinop and the amount of recycling are different. It can be said that both the amounts of total wastes and recyclable wastes increase in Sinop, which a coastal city preferred for tourism in the summer months. Moreover, there are also street recycling collector activities. In the city, there are two registered street recycling collectors under the control of municipal police.

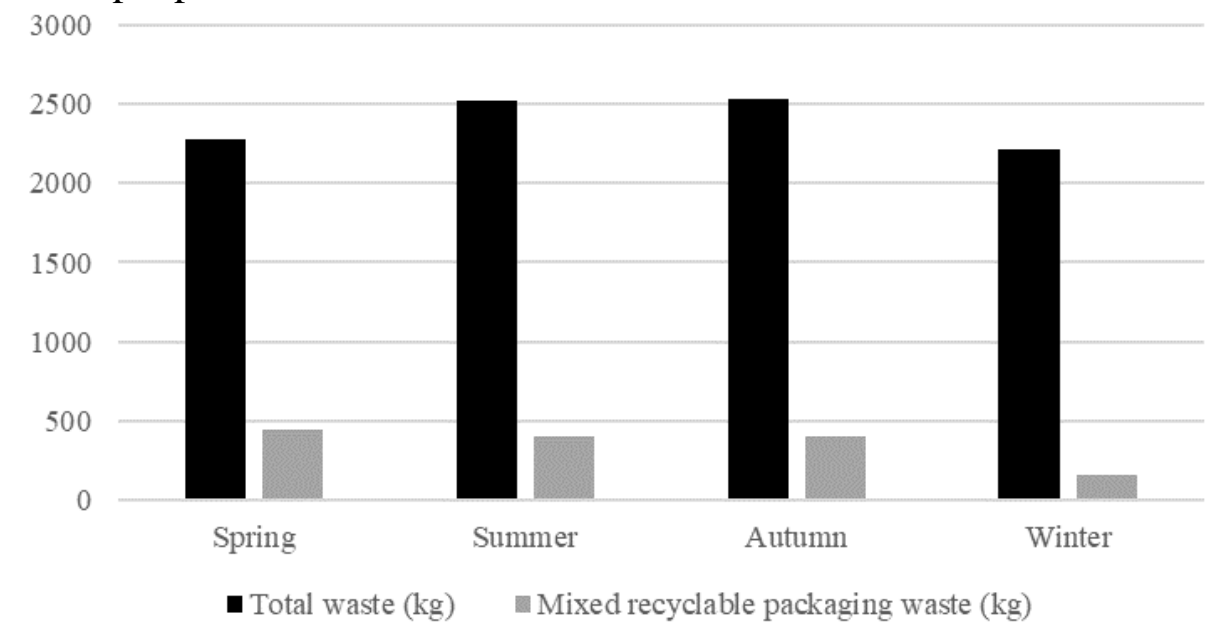

Figure 4. Comparison of waste and recycling data for 2015 (Anonymous, 2017a)

The collection process is provided with containers and cages supplied by the company and with bags given by the company at some points. The process is carried out by collection staff by first receiving mixed packaging wastes and then replacing them. Accordingly, ratios of the compositions of the wastes collected in the city center of Sinop were evaluated on three different regions with respect to low, medium and high income groups (Table 3). 
Table 3. Composition and quantities of provincial solid waste recycling products according to income groups for 2015 (Anonymous, 2017a)

\begin{tabular}{|c|c|c|c|c|c|c|c|c|c|}
\hline \multirow{3}{*}{$\begin{array}{c}\text { Waste } \\
\text { composition }\end{array}$} & \multicolumn{9}{|c|}{ Income levels } \\
\hline & \multicolumn{3}{|c|}{ Low } & \multicolumn{3}{|c|}{ Middle } & \multicolumn{3}{|c|}{ High } \\
\hline & Gross & Tare & $\%$ & Gross & Tare & $\%$ & Gross & Tare & $\%$ \\
\hline $\begin{array}{l}\text { Domestic } \\
\text { wastes }\end{array}$ & 111.20 & 106.49 & 56.41 & 21.40 & 19.83 & 24.41 & 81.34 & 76.63 & 32.34 \\
\hline Paper & 8.12 & 5.96 & 3.16 & 3.88 & 2.80 & 3.45 & 27.97 & 26.40 & 11.14 \\
\hline Cardboard & 10.62 & 7.48 & 3.96 & 8.59 & 7.02 & 8.64 & 9.61 & 8.04 & 3.39 \\
\hline $\begin{array}{l}\text { Bulky } \\
\text { cardboard }\end{array}$ & & & 4.28 & & 2.71 & 3.33 & 18.08 & 14.94 & 6.30 \\
\hline Plastic & 60.80 & 28.08 & 14.88 & 49.62 & 25.08 & 30.86 & 62.82 & 38.28 & 16.15 \\
\hline Glass & 17.56 & 13.63 & 7.22 & 9.12 & 7.81 & 9.61 & 13.27 & 11.72 & 4.95 \\
\hline Metal & 5.33 & 3.47 & 1.84 & 1.21 & 0.90 & 1.11 & 2.78 & 2.16 & 0.91 \\
\hline Other burning & 19.04 & 17.47 & 9.26 & 16.68 & 15.11 & 18.59 & 45.73 & 44.80 & 18.91 \\
\hline Others (ash) & 6.17 & 6.17 & 3.27 & & & & 14.00 & 14.00 & 5.91 \\
\hline Total & 238.84 & 188.75 & 100 & 114.78 & 81.26 & 100 & 275.6 & 236.97 & 100 \\
\hline
\end{tabular}

The collection of mixed packaging wastes has continued throughout the city. The data for the recycled materials registered from the 2015 and initial data of 2016 are shown in Figure 5.

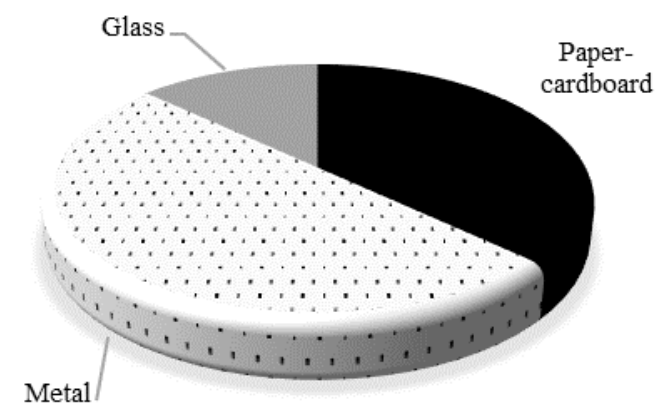

Figure 5. Evaluation of recorded parts of recycled products collected from 2015 and initial data of 2016 (Anonymous, 2017a)

Table 4 shows the unit price of packaging wastes processed on the market in December 2015 and the amount of waste collected in the same month within the provincial borders. It should be noted that unit prices and collected packaging waste amounts reveal a fluctuation on a monthly basis. Rearrangements are made according to the fluctuated values.

Table 4. December 2015 waste unit price and waste quantities

\begin{tabular}{lcc}
\hline Recyclable waste & $\begin{array}{r}\mathbf{2 0 1 5} \text { December waste unit price } \\
\left(\mathrm{kg} . \mathrm{E}^{-1}\right)\end{array}$ & $\begin{array}{c}\text { Collective waste quantities } \\
(\mathrm{kg})\end{array}$ \\
\hline Paper cardboard & 0.15 & 22000 \\
Glass & 0.10 & 1500 \\
Nylon & 0.70 & 600 \\
Plastic (PET PVC PP PS PE) & 0.70 & 1000 \\
\hline
\end{tabular}

The change in the unit prices of mixed packaging wastes varies depending on the abundance ratio of the waste in the market. For example, the unit price of the waste type, which is abundant in the market, shows a decrease for that period.

In addition to the applications for mixed packaging wastes, there are also works for waste batteries carried out by the authorized company. The total amount of waste batteries collected between 2013 and 2014 was found to be $748.37 \mathrm{~kg}$ and this amount was documented as $568 \mathrm{~kg}$ in the 2014-2015 years. 


\section{CONCLUSION}

Of approximately 25 million tons of domestic solid wastes formed annually in Turkey, 3 million tons which correspond almost to $12 \%$ of the total, are the packaging wastes defined as recyclable wastes and the priority of solid waste recycling works is the revaluation of packaging materials. To recycle these wastes for economy, the works initiated by the Ministry of Environment for "packaging wastes" have been carried out since 1992 (TCA, 2004; Fettahoğlu, 2011).

Within the scope of this study, the recycling possibilities of municipal wastes in the city center of Sinop and the sustainability of the works were investigated with the data of 2015. The collection of domestic wastes formed in the city is carried out by the Municipality. Packaging wastes are collected by a special Waste Collection and Recycling Ind. Trade Ltd. Com. examining generally the composition of the waste formed in the city, the composition is as follows: $44 \%$ of paper-cardboard, $22 \%$ of glass, $17 \%$ of PET PVC PP PS PE, $17 \%$ of metals, $68 \%$ of organic wastes (organic waste, textile and garden wastes). However, according to Sinop 2016 Environmental Status Report, the recovery rate to be recovered in 2016 is $52 \%$ (Anonymous, 2017).

There are not substantial changes observed in monthly waste profile and amounts except summer months. Recyclable wastes account for $18 \%$ among total waste amounts. The majority of the organic wastes formed is sent to regular storehouse. The numbers reached by the province in separate collection activities are quite satisfactory in terms of sustainability. However, the assessment of recycled wastes by provincial municipality and companies in a more regular data infrastructure will be more appropriate to make a long-term plan. The formation of significant data infrastructure for total and recyclable wastes is critical for long-term waste management planning. There are also works performing for packaging wastes, park-garden wastes, waste batteries, debris construction wastes and the management of waste oils.

As a result, it can be generally said that Sinop has been successful in terms of waste management. In order for waste management to be carried out without any problem, it is important to first raise the awareness of consumers and then solve legal, economic and political problems in terms of the sustainability of waste management.

\section{ACKNOWLEDGEMENTS}

The authors owe thanks to anonymous reviewers for many penetrating comments.

\section{REFERENCES}

Anonymous, 2006. Katı Atık Yönetimi Yasal Düzenlemeler ve Sinop Örneği, http://www.yerelnet.org.tr/yerel_hizmetler/kati_atik/rapor. (date of access: 09.02.2017)

Anonymous, 2008. Meşedağ Solid Waste Disposal Facility Introduction, Sinop Municipality, http://www.sinop.bel.tr/index.php (date of access: 16.01.2017)

Anonymous, 2017. Sinop Provincial Directorate of Environment and Urbanization (PDEU), 2017, Provincial Environmental Status Report 2016, Sinop, 126 p.

Anonymous, 2017a. Solid Waste Report of Union of Coastal Municipalities of Sinop, 2017, Sinop, 24 p.

Fettahoğlu F, 2011. İstanbul Başakşehir Bölgesi Kentsel Katı Atıkların Geri Kazanım Olanaklarının İncelenmesi. Ondokuz Mayıs Üniversitesi, Fen Bilimleri Enstitüsü, Yüksek Lisans Tezi, 160 s, Samsun.

Gökkurt Baki O, Ergun ON, 2015. Example of Coastal Settlement Investigation of Solid Waste Management in Sinop, 7th National Solid Waste Management Congress, UKAY 2015, 14-16 October, Abstract Book, 65 p. Gaziantep.

Guerrero LA, Maas G, Hogland W, 2013. Solid Waste Challenges for Cities in Developing Countries, Waste management, 33(2013): 220-232. 
Gupta N, Yadav KK, Kumar V, 2015. A Review on Current Status of Municipal Solid Waste Management in Indiad, Journal of Environmental Sciences, 37(2015): 206-217.

Herat S, 2009. Electronic Waste: An Emerging Issue in Solid Waste Management in Australia. Int. J. Environ. Waste Manag., 3(1/2), 120-134.

IB, 2004. Special Conditions of Solid Waste Facilities, Bank of Provinces, Ankara.

Jha, A. K., Singh, S. K., Singh, G. P., Gupta, P. K. 2011. Sustainable Municipal Solid Waste Management in Low Income Group of Cities: A Review. Int. Soc. Trop. Ecol., 52(1), 123-131.

Minghua Z, Xiumin F, Rovetta A, Qichang H, Vicentini F, Binghai L, Giusti A, Yi L, 2009. Municipal Solid Waste Management in Pudong New Area, China, Journal of Waste Management 29, 1227-1233.

MSÜ, 2005. Sinop Construction Plan Study, Mimar Sinan University, 168 p, Istanbul.

Palabıyık H, Altunbaş D, 2004. Kentsel Katı Atıklar ve Yönetimi, Çevre Sorunlarına Çağdaş Yaklaşımlar: Ekolojik, Ekonomik, Politik ve Yönetsel Perspektifler (C. Marin, U. Yıldırım ed.), Beta Yayınları, 103124. İstanbul.

SCOM, 2005. Sinop Provincial Directorate of Environment and Forestry, Sinop Province Environmental Status Report for 2004, 32 p, Sinop.

SB, 2009. Preliminary Report of Sinop-Erfelek Dam, Transmission Line and Expansion Plant Project. Ministry of Environment and Forestry, General Directorate of State Hydraulic Works (DSI), Directorate of Drinking Water and Sewerage Department, Ankara.

TCA, 2004. Environmental Atlas of Turkey, Ministry of Environment and Forestry, Ankara, 2004.

Tchobanoglous G, Theisen H, Vigil SA, 1993. Integrated solid waste management-engineering Principles and Management Issues, Tata McGraw Hil International Edition.

Turan T, Ekmekyapar F, 2009. Problems Encountered in Solid Waste Management in Our Country and Solutions, TÜRKAY 